\title{
Alpha-fetoprotein can regulate growth in the uterus of the immature and adult ovariectomized mouse
}

\author{
G. J. Mizejewski and A. S. Warner \\ Wadsworth Center for Laboratories \& Research, New York State Department of Health, Albany, \\ NY 12201, USA
}

\begin{abstract}
Summary. This is a report of development of (1) a 3-day immature mouse bioassay for alpha-fetoprotein (AFP) to increase the working range in uterine wet weights overcoming seasonality, and (2) a bioassay for AFP performed with ovariectomized adult mice to increase sensitivity. Mouse AFP was isolated from amniotic fluid and purified by polyacrylamide gel electrophoresis followed by Blue Sepharose chromatography. The uterine growth evoked by the injection of $1.0 \mu \mathrm{g}$ AFP together with excess molar oestradiol $(0.5 \mu \mathrm{g})$ over a $23-\mathrm{h}$ period was compared in immature ovariectomized adult Nylar mice. The 3-day assay with immature mice was rendered usable in any season, with sensitivity comparable to the 1-day assay. Increased sensitivity, however, was demonstrated by utilization of AFP in a 1-day assay with the adult ovariectomized mouse.
\end{abstract}

Keywords: alpha-fetoprotein; growth; regulation; uterus; mouse; bioassay

\section{Introduction}

Alpha-fetoprotein (AFP) is a glycoprotein of $M_{\mathrm{r}} 70000$ first discovered in human fetal blood by Bergstrand \& Czar (1957). It was later found in the blood of hepatoma-bearing mice by Abelev $e t$ al. (1963) and in tumour-bearing human patients by Tatarinov (1964). Further research indicated that certain AFPs could bind oestrogen as well as other ligands (Aoyagi et al., 1978; Savu et al., 1981). It was subsequently reported that AFP displayed growth-regulatory properties (Abelev, 1971; Soubiran et al., 1979; Toder et al., 1983; Mizejewski \& Jacobson, 1987). Clinically, the presence of this tumour-associated fetal protein has been exploited for screening purposes (Kithier et al., 1966; Brock \& Sutcliffe, 1972; Leek et al., 1973) but its growth-regulatory potential has remained largely untapped.

AFP inhibits the oestrogen-stimulated uterine growth response in immature mice when the AFP is incubated with excessive amounts of oestradiol for $1 \mathrm{~h}$ before injection (Mizejewski et al., 1983, 1986). This inhibitory effect of oestradiol-activated AFP cannot be explained simply by the ability of this molecule to bind to and sequester oestrogen (Raynaud, 1973), since a significant inhibitory effect was seen when the molar amount of AFP in the reaction mixture was less than $1 \%$ of the molar amount of oestradiol employed, and subsequent additional injections of oestradiol in an amount well in excess of that which AFP could sequester could not overcome the inhibition (Mizejewski et al., 1983). The effect is protein specific for AFP being non-reactive with albumin and transferrin and steroid-specific for oestradiol and oestrone but not moxoestrol. Therefore, we proposed that the antiuterotrophic action of AFP represents a growth regulatory property of the molecule.

Purified mouse AFP preparations that are stored for prolonged periods progressively lose their growth-inhibiting activity and ultimately acquire a growth-potentiating activity: both biological 
activities co-existed in fresh amniotic fluid and resided in different fractions which could be separated by oestradiol-affinity chromatography (Mizejewski \& Jacobson, 1987). The decayed inhibitory activity of AFP can also be regenerated in aged AFP preparations by treatment with high salt $(0.4 \mathrm{M}-\mathrm{KCl})$. It would therefore appear that AFP has molecular variants which, depending on their relative abundance in the preparation, constitute a mixture in mouse amniotic fluid which is capable of (a) growth inhibition, (b) no effect on cell growth, or (c) growth enhancement. To study further these varied activities, we needed to discriminate better smaller differences in uterine wet weight and increase the sensitivity of our AFP bioassay system (Mizejewski et al., 1986).

In the present report, we describe our development of (1) an immature mouse bioassay extended to 3 days to increase the working range in uterine wet weights to overcome its seasonality limitations and (2) a bioassay for AFP performed in the ovariectomized adult mouse to increase sensitivity. Secondly, we have validated data from those obtained with the immature mouse 1-day assay, for the study of the antiuterotrophic and the potentiating activities of murine AFP. Finally, we hoped to demonstrate that AFP preparations could display biological activity equally as well in adult as in neonatal mouse uterine tissue.

\section{Materials and Methods}

Animals. Pregnant mice of the outbred Nya:NYLAR strain (henceforth referred to as Nylar) were obtained from Griffin Laboratory (New York State Department of Health, Albany, NY, USA). After delivery of young, families were housed in separate cages and the date of birth was recorded. Animals were fed laboratory chow ad libitum and maintained on $14 \mathrm{~h}$ light: $10 \mathrm{~h}$ dark cycles. Male young were removed after birth and female young remained with their mothers until autopsy. The immature female mice used for this study ranged from 15 to 18 days of age and weighed $5.8 \mathrm{~g}$. Adult Nylar female mice, $25-30 \mathrm{~g}$, were used for studies involving ovariectomized animals. All animals were killed by decapitation before the collection of blood, amniotic fluid or uteri as previously described (Mizejewski et al., 1983, 1986).

Biochemical and immunochemical methods. Protein in amniotic fluid and in AFP isolates was determined by the method of Lowry et al. (1951). AFP concentrations were determined using the radial immunodiffusion procedure (Mancini et al., 1965) and by rocket electrophoresis (Laurell, 1966) with a purified AFP standard of hepatoma origin (Allen \& Mizejewski, 1977). Rocket electrophoresis was also used to quantitate AFP in sera obtained from immature mice. Purity of AFP preparations was ascertained by immunoelectrophoresis (Scheidigger, 1955) and by immunodiffusion (Ouchterlony, 1968) as previously detailed (see below).

Purification of AFP from amniotic fluid. Mouse amniotic fluid was obtained by puncturing the amniotic sacs of 15-18-day-pregnant Nylar animals using a tuberculin syringe fitted with a 26-gauge needle. Amniotic fluid was pooled, centrifuged $(1800 \mathrm{~g}, 10 \mathrm{~min})$, filtered $(0.45 \mu \mathrm{m}$ Millipore $)$, and stored at $-20^{\circ} \mathrm{C}$. Total protein in the fluid was $3.0 \mathrm{mg} / \mathrm{ml}$ and the AFP concentration was $1.0 \mathrm{mg} / \mathrm{ml}$.

AFP from mouse amniotic fluid was purified by preparative polyacrylamide gel electrophoresis (PAGE), using discontinuous gradient polyacrylamide gels (Joshi \& Ebert, 1976). The lyophilized product was reconstituted and dialysed against phosphate-buffered saline (PBS), $\mathrm{pH} 7 \cdot 2$. This preparation was freed of residual albumin by affinity chromatography on Blue Sepharose (Kelleher et al., 1979). Quantitation of AFP in each purified protein preparation was performed both by analysis for total protein and for immunoreactive AFP by rocket electrophoresis.

All AFP preparations fulfilled the criteria of purity that were previously described (Mizejewski et al., 1979a, b). These include: presence of a single band after polyacrylamide gel electrophoresis, a single line of precipitation with an antiserum against mouse amniotic fluid which normally produces 3-4 precipitin lines when challenged with amniotic fluid, a single precipitin arc in the alpha-1 position after immunoelectrophoresis with anti-mouse amniotic fluid, failure to produce a precipitin line against rabbit antisera to adult mouse serum proteins, and production of monospecific antibodies against mouse AFP when used to immunize guinea-pigs and/or rabbits.

Other materials from mouse amniotic fluid that were examined were amniotic fluid incubated for $15 \mathrm{~min}$ at $4^{\circ} \mathrm{C}$ with a suspension of dextran-coated Norit charcoal (Sigma, St Louis, MO, USA) (Mizejewski et al., 1980), followed by centrifugation for $10 \mathrm{~min}$ at $3000 \mathrm{~g}$. This treatment has been reported to convert inactive AFP to an active form (Mizejewski et al., 1983).

Antiserum production and its specificity. The production of rabbit antiserum to AFP purified from mouse amniotic fluid has been described (Mizejewski \& Allen, 1978). Immunoelectrophoresis of mouse amniotic fluid against this antiserum produced a single precipitation arc in the alpha-1 region. By immunodiffusion it formed a single band of identity against mouse amniotic fluid, which was continuous with a band formed against purified AFP of hepatoma origin (Allen \& Mizejewski, 1977). Finally, the antiserum produced a single peak when subjected to rocket electroimmunodiffusion against mouse amniotic fluid in purified and crude preparations. 
Oestrogen response in the uterus of the immature mouse. Stock solutions of oestradiol- $17 \beta$ in $95 \%$ ethanol $(100 \mu \mathrm{g} /$ $\mathrm{ml}$ ) were diluted with phosphate-buffered saline ( $\mathrm{pH} 7 \cdot 2)$ to produce injectants containing $0.5 \mu \mathrm{g}$ oestradiol in $100 \mu \mathrm{l}$ solution. With a tuberculin syringe equipped with a 26-gauge needle, immature female mice were injected intra. peritoneally (i.p.) with $100 \mu \mathrm{l}$ of this oestradiol solution and/or protein mixtures and were returned to their original cage. The transient increase in uterine weight that this treatment evokes is maximal $20-24 \mathrm{~h}$ after the injection and is the result of cell proliferation as determined by mitotic indices (Mizejewski et al., 1983). For convenience, a standard 23-h interval was adopted. After that time, the mice were weighed, decapitated and bled. The uteri were exposed by a midventral incision and the ovary and oviduct were dissected away from the anterior portion of each of the uterine horns. A posterior cut at the corpus uteri was used to free the organ from the vaginal chamber. The uteri were trimmed free of mesenteries and immediately weighed. The ratio of uterine to body weight was calculated to normalize differences in body weight among litters of the same age.

We also examined the AFP response to the uterine growth in Nylar young given a single injection of oestradiol$17 \beta$ and oestradiol-17 + AFP on 1, 2 or 3 days in succession. Mice were then killed on the day after the last injection.

Oestrogen response in the uterus of ovariectomized adult mice. Adult virgin female Nylar mice were ovariectomized under anaesthesia with $0.3 \mathrm{ml}$ pentobarbitone sodium $(50 \mathrm{mg} / \mathrm{ml}$ diluted $1: 10$ with PBS, pH $7 \cdot 2)$ and were randomly assigned to treatment groups. Oestradiol- $17 \beta(0.05-2.5 \mu \mathrm{g})$ in $100 \mu \mathrm{l}$ volumes containing $5 \%$ ethanol was given i.p. at 10 days after ovariectomy. Other groups were non-injected littermates. PBS-ethanol controls were similar to the untreated controls as found in immature mice (Mizejewski et al., 1983). Uterine weights were determined at autopsy $23 \mathrm{~h}$ after injection. In one experiment, purified mouse AFP in doses of $0 \cdot 1,1 \cdot 0,5 \cdot 0,10,20$ and $40 \mu \mathrm{g}$ per mouse was titrated with $0.5 \mu \mathrm{g}$ oestradiol- $17 \beta$ for testing in the adult ovariectomized mouse.

'Bioassay' for inhibition or enhancement by AFP of oestrogen-induced uterine growth. Kinetic studies have shown that the binding of oestradiol to AFP preparations is a complex process which is complete after $1 \mathrm{~h}$ of incubation (Mizejewski et al., 1982). Therefore, the oestradiol injectant solution was incubated at $25^{\circ} \mathrm{C}$ with various amounts of amniotic fluid or purified AFP preparations $1 \mathrm{~h}$ before its administration to the mice. Each $100 \mu \mathrm{l}$ PBS for injection contained $0.5 \mu \mathrm{g}$ oestradiol and different amounts of the AFP solution under test, usually $1.0 \mu \mathrm{g}$. At $23 \mathrm{~h}$ after injection, the immature and/or ovariectomized adult mice were autopsied and uterine weights determined as described above. The effect of the protein is expressed as the change that its inclusion in the injectant has imposed on the oestrogen-stimulated gain in uterine weight, expressed as a percentage of oestradiol-stimulated weight gain:

$$
\text { inhibition }=100 \times(E-E P) /(E-C)
$$

in which $\mathrm{E}$ and $\mathrm{EP}$ are the mean uterine weight $\mathrm{mg} / \mathrm{g}$ body weight in the groups given oestradiol and oestradiol + AFP respectively, and $C$ is the mean for untreated controls. Unless otherwise stated, all single-day bioassays used $1.0 \mu \mathrm{g}$ purified mouse AFP together with $0.5 \mu \mathrm{g}$ oestradiol-17 $\beta$ per injection.

Storage procedures ('aged' AFP). Purified AFP preparations were routinely dispensed into $50 \mu$ amounts and stored frozen $\left(-20^{\circ} \mathrm{C}\right)$. Both storage at $-20^{\circ} \mathrm{C}$ for 4 weeks or longer or 3 freeze/thaw cycles are known to produce aged AFP preparations as previously described (Mizejewski \& Jacobson, 1987).

Statistical procedures. Values are presented as the mean and standard error of the mean (s.e.). The statistical significance of differences between treatment groups was assessed by a non-parametric method, the Wilcoxon sum of ranks test, testing a null hypothesis and applying either a one- or two-tailed test. Data were considered to be significant at or below the $5 \%$ level.

\section{Results}

\section{Bioassay of 3 days for AFP regulation of oestradiol-induced uterine growth}

During the 'low sensitivity' season we examined uterine growth in groups of young given 1,2 or 3 daily injections of oestradiol or oestradiol + AFP (Table 1). The degree of inhibition after 3 days of treatment was sufficient to prepare a dose-response standard curve of antiuterotrophic activity (Fig. 1a).

A dose response curve for the uterine growth-potentiating activity of aged AFP was also generated following 3 days of treatment (Fig. $1 \mathrm{~b}$ ). The maximum inhibition as well as maximum enhancement activity occurred at the same daily dose of AFP (1.0 $\mu \mathrm{g}$ daily).

\section{Oestrogen-induced uterine growth in the ovariectomized mouse}

As shown in Fig. 2, the largest oestrogen dose, $2.5 \mu \mathrm{g}$ /mouse, produced a uterine wet weight 4 times that found in untreated ovariectomized controls and comparable to that found in cycling intact females (see Table 3). 
Table 1. Comparison of uterine to bodyweight ratios during the low season in control and treatment groups of immature Nylar mice assayed for 1, 2 and 3 days

\begin{tabular}{|c|c|c|c|c|c|c|}
\hline \multirow{2}{*}{$\begin{array}{l}\text { Duration } \\
\text { of assay }\end{array}$} & \multirow[b]{2}{*}{ Treatment } & \multirow{2}{*}{$\begin{array}{l}\text { No. of } \\
\text { mice }\end{array}$} & \multicolumn{2}{|c|}{ Uterine:body weight } & \multirow[b]{2}{*}{$\%$ inhibition } & \multirow[b]{2}{*}{ Significance } \\
\hline & & & Mean & s.e. & & \\
\hline 1 day & $\begin{array}{l}\text { Untreated control } \\
\mathrm{E}_{2} \text { alone } \\
\text { AFP/E }\end{array}$ & $\begin{array}{l}6 \\
7 \\
6\end{array}$ & $\begin{array}{l}0 \cdot 90 \\
1 \cdot 30 \\
1 \cdot 17\end{array}$ & $\begin{array}{l}0.04 \\
0.06 \\
0.06\end{array}$ & $\begin{array}{l}\text { NA } \\
\text { NA } \\
33\end{array}$ & $\begin{array}{c}\text { NA } \\
\text { NA } \\
P<0.025\end{array}$ \\
\hline 2 days & $\begin{array}{l}\text { Untreated control } \\
E_{2} \text { alone } \\
\text { AFP/E } E_{2}\end{array}$ & $\begin{array}{l}9 \\
9 \\
6\end{array}$ & $\begin{array}{l}0.94 \\
1 \cdot 58 \\
1 \cdot 30\end{array}$ & $\begin{array}{l}0.02 \\
0.06 \\
0.07\end{array}$ & $\begin{array}{l}\text { NA } \\
\text { NA } \\
44\end{array}$ & $\begin{array}{c}\text { NA } \\
\text { NA } \\
P<0.025\end{array}$ \\
\hline 3 days & $\begin{array}{l}\text { Untreated control } \\
E_{2} \text { alone } \\
\text { AFP/E } E_{2}\end{array}$ & $\begin{array}{l}11 \\
10 \\
10\end{array}$ & $\begin{array}{l}1 \cdot 13 \\
2 \cdot 06 \\
1 \cdot 52\end{array}$ & $\begin{array}{l}0.03 \\
0.05 \\
0.04\end{array}$ & $\begin{array}{l}\text { NA } \\
\text { NA } \\
58\end{array}$ & $\begin{array}{c}\text { NA } \\
\text { NA } \\
P<0.01\end{array}$ \\
\hline
\end{tabular}

$\mathrm{E}_{2}=$ oestradiol-17ß $(0.5 \mu \mathrm{g}) ; \mathrm{NA}=$ not applicable; $\mathrm{NS}=$ not significant.

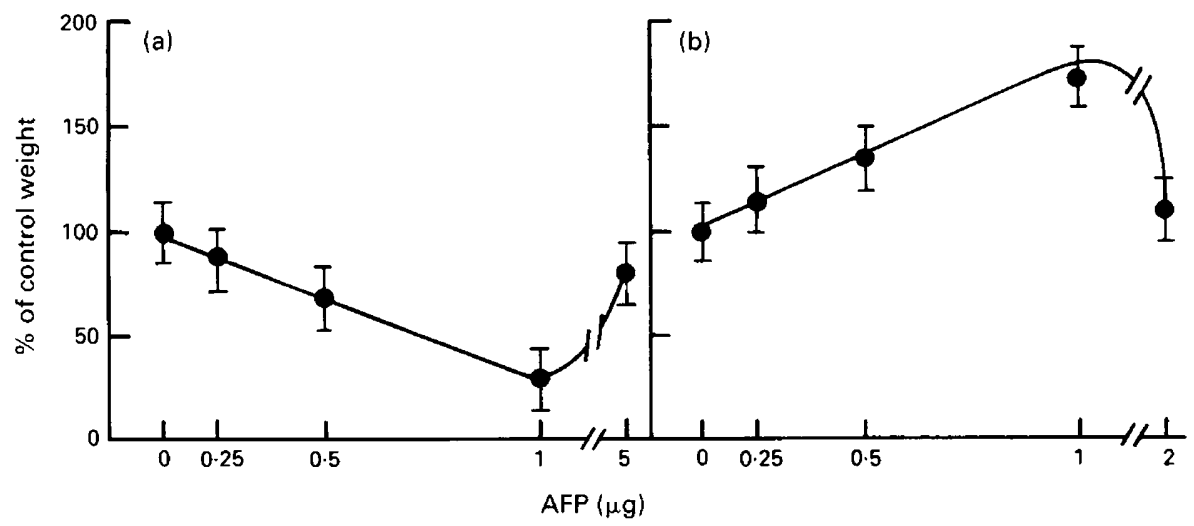

Fig. 1. A dose--response curve for the uterine growth inhibition (a) and potentiating activity (b) of purified mouse AFP generated after 3 days of treatment. Animals were killed on Day 4. Values are means \pm s.e. for $5-6$ mice per point.

\section{Bioassay for AFP activity performed in adult ovariectomized mice}

As displayed in Table 2, doses of $0 \cdot 1,1 \cdot 0$ and 5.0 $\mu \mathrm{g}$ AFP each inhibited by at least one-third $(P<0.005$ to 0.05$)$ the uterine growth induced by $0.5 \mu \mathrm{g}$ oestradiol-17 3 , whereas doses of 10,20 and $40 \mu \mathrm{g} \mathrm{AFP/mouse} \mathrm{were} \mathrm{without} \mathrm{significant} \mathrm{effect}(P>0.05)$. In the adult ovariectomized mouse, therefore, the co-administration of $1 / 1300$ mole fraction of AFP with $0.5 \mu \mathrm{g}$ oestradiol effects inhibition of the uterotrophic response to the oestrogen, while in the immature mouse 10 times more AFP is required for nearly similar results (Table 2). The largest inhibition observed $(82 \%)$ was imposed by $5.0 \mu \mathrm{g}$ AFP on the much larger uterine growth that was elicited by $2.5 \mu \mathrm{g}$ oestradiol (Table 3). In contrast, AFP that is contained in mouse amniotic fluid had no activity, while charcoal treatment of this amniotic fluid generated some growth-inhibitory effect (Table 4). These results were comparable to those of studies with immature mice with $57 \%$ inhibition in the former and $45 \%$ in the latter (Table 4).

Purified mouse AFP preparations that had been stored at $-20^{\circ} \mathrm{C}$ for 12 weeks produced a $12 \%$ potentiating effect $(P<0.05)$ in the ovariectomized adult mouse, comparable to a $10 \%$ potentiating effect in the immature mouse (Table 5). 


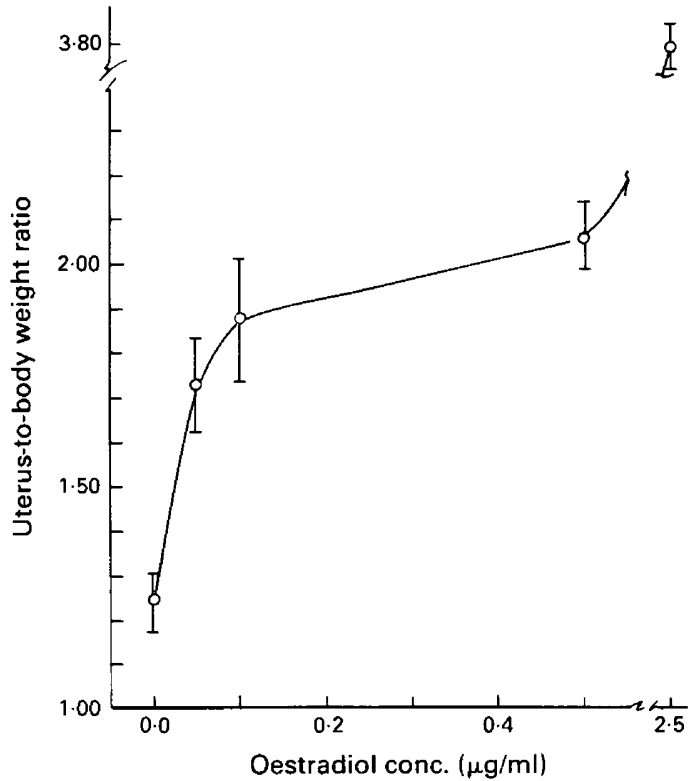

Fig. 2. The dose-response relationship for oestradiol-induced growth in the adult ovariectomized mouse uterus after $23 \mathrm{~h}$. Values are means \pm s.e. for $10-12$ mice per point.

Table 2. Uterine to body weight ratios in immature mice and ovariectomized adult mice in a 1-day assay

\begin{tabular}{|c|c|c|c|c|c|c|}
\hline \multirow[b]{2}{*}{ Mice } & \multirow[b]{2}{*}{ Treatment } & \multirow{2}{*}{$\begin{array}{l}\text { No. of } \\
\text { mice }\end{array}$} & \multicolumn{2}{|c|}{ Uterine:body weight } & \multirow[b]{2}{*}{$\%$ inhibition } & \multirow[b]{2}{*}{ Significance } \\
\hline & & & Mean & s.e. & & \\
\hline \multirow{3}{*}{ Immature } & 0 (controls) & 28 & $1 \cdot 03$ & 0.09 & NA & NA \\
\hline & $\begin{array}{l}0.5 \mu \mathrm{g} \mathrm{E}_{2} \\
1.0 \mu \mathrm{g} \text { AFP }\end{array}$ & 22 & 1.66 & $0 \cdot 15$ & NA & NA \\
\hline & $+0.5 \mu \mathrm{g} \mathrm{E}_{2}$ & 23 & $1 \cdot 37$ & $0 \cdot 15$ & 46 & $P<0.025$ \\
\hline \multirow[t]{8}{*}{ Adult } & 0 (controls) & 25 & $1 \cdot 22$ & 0.06 & NA & NA \\
\hline & $\begin{array}{l}0.5 \mu \mathrm{E}_{2} \\
\text { Purified AFP + } \\
0.5 \mu \mathrm{E}\end{array}$ & 24 & $2 \cdot 22$ & 0.07 & NA & NA \\
\hline & $0.1 \mu \mathrm{g}$ & 6 & 1.92 & $0 \cdot 16$ & 30 & $P<0.05$ \\
\hline & $1.0 \mu \mathrm{g}$ & 6 & 1.87 & 0.09 & 35 & $P<0.025$ \\
\hline & $5.0 \mu \mathrm{g}$ & 10 & 1.90 & $0 \cdot 10$ & 32 & $P<0.005$ \\
\hline & $10 \cdot 0 \mu \mathrm{g}$ & 10 & 1.94 & 0.08 & 28 & NS \\
\hline & $20.0 \mu \mathrm{g}$ & 3 & 1.99 & $0 \cdot 14$ & 23 & NS \\
\hline & $40.0 \mu \mathrm{g}$ & 3 & $2 \cdot 11$ & 0.12 & 11 & NS \\
\hline
\end{tabular}

$\mathrm{E}_{2}=$ oestradiol-17ß; $\mathrm{NA}=$ not applicable; $\mathrm{NS}=$ not significant.

\section{Discussion}

In previous studies of uterine growth in immature mice, we have found that oestrogen-supported growth fails when the animals are injected with a regulator substance formed as the reaction product of AFP in excessive amounts of oestradiol-17ß (Mizejewski et al., 1983). Albumin and 
Table 3. Uterine to body weight ratios in control and treatment groups of adult ovariectomized (ovex) and cycling intact mice in a 1-day assay

\begin{tabular}{|c|c|c|c|c|c|}
\hline \multirow[b]{2}{*}{ Treatment } & \multirow{2}{*}{$\begin{array}{l}\text { No. of } \\
\text { mice }\end{array}$} & \multicolumn{2}{|c|}{ Uterine:body weight } & \multirow[b]{2}{*}{$\%$ inhibition } & \multirow[b]{2}{*}{ Significance } \\
\hline & & Mean & s.e. & & \\
\hline 0 (control, cyclic) & 12 & $4 \cdot 15$ & 0.48 & NA & NA \\
\hline 0 (control, ovex) & 8 & 1.23 & 0.06 & NA & NA \\
\hline $2.5 \mu \mathrm{g} \mathrm{E}_{2}$ (ovex) & 5 & $3 \cdot 80$ & 0.59 & NA & NA \\
\hline $\begin{array}{l}5.0 \mu \mathrm{g} \mathrm{AFP}+2.5 \mu \mathrm{g} \mathrm{E}_{2} \\
\text { (ovex) }\end{array}$ & 5 & 1.68 & 0.32 & 82 & $P<0.01$ \\
\hline
\end{tabular}

$\mathrm{E}_{2}=$ oestradiol-17ß; $\mathrm{NA}=$ not applicable.

Table 4. Uterine to body weight ratios in immature mice and ovariectomized adult mice treated with mouse amniotic fluid (MAF) in a 1-day assay

\begin{tabular}{|c|c|c|c|c|c|c|}
\hline \multirow[b]{2}{*}{ Animals } & \multirow[b]{2}{*}{ Treatment } & \multirow{2}{*}{$\begin{array}{l}\text { No. of } \\
\text { mice }\end{array}$} & \multicolumn{2}{|c|}{ Uterine:body weight } & \multirow[b]{2}{*}{$\%$ inhibition } & \multirow[b]{2}{*}{ Significance } \\
\hline & & & Mean & s.e. & & \\
\hline \multirow{4}{*}{ Immature } & 0 (controls) & 29 & $0 \cdot 90$ & 0.03 & NA & NA \\
\hline & $\begin{array}{l}0.5 \mu \mathrm{g} \mathrm{E}_{2} \\
1.0 \mu \mathrm{g} \mathrm{MAF} / \mathrm{AFP}\end{array}$ & 30 & $1 \cdot 64$ & 0.03 & NA & NA \\
\hline & $\begin{array}{c}+0.5 \mu \mathrm{g} \mathrm{E}_{2} \\
1.0 \mu \mathrm{MAF} / \mathrm{AFP}\end{array}$ & 12 & 1.51 & 0.04 & 18 & NS \\
\hline & $+0.5 \mu \mathrm{g} \mathrm{E}_{2}$ (charcoal) & 26 & $1 \cdot 31$ & 0.04 & 45 & $P<0.005$ \\
\hline \multirow[t]{4}{*}{ Adult } & 0 (controls) & 25 & $1 \cdot 22^{*}$ & 0.06 & NA & NA \\
\hline & $\begin{array}{l}0.5 \mu \mathrm{g} \mathrm{E}_{2} \\
5.0 \mu \mathrm{g} \mathrm{MAF} / \mathrm{AFP}\end{array}$ & 24 & $2 \cdot 22^{*}$ & 0.07 & NA & NA \\
\hline & $\begin{array}{c}+0.5 \mu \mathrm{g} \mathrm{E} \\
5.0 \mu \mathrm{g} \mathrm{MAF} / \mathrm{AFP}\end{array}$ & 12 & $2 \cdot 13$ & 0.07 & 9 & NS \\
\hline & $+0.5 \mu \mathrm{g} \mathrm{E}_{2}$ (charcoal) & 8 & $1 \cdot 65$ & 0.09 & 57 & $P<0.005$ \\
\hline
\end{tabular}

$\mathrm{E}_{2}=$ oestradiol-17ß; NA = not applicable; $\mathrm{NS}=$ not significant.

*Same controls were used as in Table 2 since the animals were done during the same time period.

Table 5. Uterine to body weight ratios in immature mice and ovariectomized adult mice treated with 'aged' purified mouse AFP in a 1-day assay

\begin{tabular}{|c|c|c|c|c|c|c|}
\hline \multirow[b]{2}{*}{ Animals } & \multirow[b]{2}{*}{ Treatment } & \multirow{2}{*}{$\begin{array}{l}\text { No. of } \\
\text { mice }\end{array}$} & \multicolumn{2}{|c|}{ Uterine:body weight } & \multirow[b]{2}{*}{$\%$ Potentiation } & \multirow[b]{2}{*}{ Significance } \\
\hline & & & Mean & s.e. & & \\
\hline \multirow[t]{3}{*}{ Immature } & 0 (controls) & 8 & 0.90 & 0.02 & NA & NA \\
\hline & $\begin{array}{l}0.5 \mu \mathrm{g} \mathrm{E} \mathrm{z}_{2} \\
1.0 \mu \mathrm{g} \text { 'aged' }\end{array}$ & 11 & 1.49 & 0.04 & NA & NA \\
\hline & $\mathrm{AFP}+0.5 \mu \mathrm{g} \mathrm{E}_{2}$ & 20 & 1.55 & 0.04 & 10 & $P<0.05$ \\
\hline \multirow[t]{2}{*}{ Adult } & $\begin{array}{l}0 \text { (controls) } \\
0.5 \mu \mathrm{g} \mathrm{E}_{2} \\
1.0 \mu \mathrm{g} \text { 'aged' }\end{array}$ & $\begin{array}{r}6 \\
12\end{array}$ & $\begin{array}{l}1.13 \\
1.91\end{array}$ & $\begin{array}{l}0.07 \\
0.12\end{array}$ & $\begin{array}{l}\text { NA } \\
\text { NA }\end{array}$ & $\begin{array}{l}\text { NA } \\
\text { NA }\end{array}$ \\
\hline & $\mathrm{AFP}+0.5 \mu \mathrm{g} \mathrm{E}_{2}$ & 8 & $2 \cdot 16$ & $0 \cdot 13$ & 12 & $P<0.05$ \\
\hline
\end{tabular}

$\mathrm{E}_{2}=$ oestradiol-17 $\beta ; \mathrm{NA}=$ not applicable; 'aged' $=$ purified AFP stored frozen at $-20^{\circ} \mathrm{C}$ for 6 weeks or more. 
transferrin treated in this manner and native AFP alone are ineffective. The mechanism by which the reaction product of AFP plus excess oestradiol-17 $\beta$ exerts its growth-regulatory influence on oestrogen-dependent tissue is not clear. However, evidence that the AFP/oestradiol growth regulatory effects involve a mechanism other than sequestration of oestradiol by AFP include the following (Mizejewski et al., 1983). (1) Injections of moxoestrol, a potent oestrogen that does not bind to AFP, did not overcome the oestradiol-activated AFP inhibition. (2) Incubation of AFP and oestradiol for shorter periods produced less inhibition, and treatment with AFP alone or with AFP simultaneously with oestradiol given by a different route produced no inhibition. (3) When the AFP concentration in the reaction is increased by a factor of 50 , less uterine inhibition occurred. The sequestration argument would predict inhibition to be increasing rather than decreasing under these conditions. These results indicate that the growth-regulatory activity is a consequence of an AFP + oestradiol interaction other than hormone sequestration, suggesting that oestradiol either induces a conformational change in AFP or that AFP acts as an enzyme that degrades oestradiol$17 \beta$ to an inhibitory product. We favour the former since Nunez (1986) suggested, based on his recent data, that binding of oestrogen dictates a conformational change in the AFP molecule which facilitates further oestrogen binding.

In the present report, we have confirmed our previous findings of AFP growth-regulatory action in the immature mouse uterus and subjected them to closer scrutiny by the use of an improved bioassay with adult ovariectomized mice. The maximum uterine response to steroids in vertebrates is known to be seasonal (Boyd \& Spelsberg, 1979). The oestrogen response in the uterus of immature mice $(0.5 \mu \mathrm{g}$ /mouse) tracked monthly for 2 consecutive years, in our laboratory, also displayed seasonality (Jacobson \& Mizejewski, 1985). Depending on the season, a quantitative bioassay of antiuterotrophic or potentiating activity would require a broader dose-response curve than the 23-h assay with a single AFP dose provides. We have therefore extended the working range of the uterine wet weights of our bioassay by development of a 3-day assay. To achieve an adequate working range in uterine wet weights in which several points can be adequately discriminated, a dose-response curve for inhibition of oestradiol-induced uterine growth at any season requires that the uninhibited uterine growth must exceed $5.0 \mathrm{mg}$. Further, this must be obtainable in the season of low uterine responsiveness if the procedure is to have year-around utility. This has been achieved by utilization of the 3-day bioassay procedure (Table 1; Fig. 1) in which 3 daily doses of AFP plus oestradiol-17 $\beta$ are administered to immature female mice. This AFP assay is similar to the standard 3-day mouse bioassay for steroids (Hilgar \& Palmore, 1965). Although the assay was rendered usable in any season, its sensitivity (i.e. minimum dose of AFP) was not measurably improved over the 1-day assay.

Increased sensitivity was, however, achieved by performance of the single-dose 23-h AFP bioassay in the adult ovariectomized mouse. In such animals, at 10 days after ovariectomy, $0.5 \mu \mathrm{g}$ oestradiol-17 $\beta$ generated a mean uterine growth of $110 \mathrm{mg} / \mathrm{g}$ body weight or $30 \mathrm{mg}$ uterine wet weight per mouse (Table 3). The greatest inhibition of $0.5 \mu \mathrm{g}$ oestradiol-induced uterine growth ( $35 \%$ or about $10 \mathrm{mg}$ wet weight) was obtained with a $1.0 \mu \mathrm{g}$ dose of AFP. The range of 0 to $10 \mathrm{mg}$ wet uterine weight was found to be adequate for generation of a growth-inhibition standard curve. Inhibition of uterine growth in ovariectomized mice was also produced by $0 \cdot 1 \mu \mathrm{g}$ AFP, which was only $10 \%$ of the dose required to produce such inhibition in the immature mouse. However, $5.0 \mu \mathrm{g}$ AFP together with $2.5 \mu \mathrm{g}$ oestradiol imposes an impressive $82 \%$ inhibition on uterine growth (Table 3). Comparable results were also produced for potentiation of uterine growth by 'aged' AFP (Table 5) when the ovariectomized mouse assay was compared to that of the immature mouse uterus assay. The adult ovariectomized mouse, with greater sensitivity and range of oestradiolstimulated uterine growth (wet weight) and low circulating AFP, appears to be suitable for study of the growth-inhibitory and -enhancing properties of mouse AFP.

Although a dose-response for the uterine growth-inhibitory property of mouse AFP has already been described (Mizejewski et al., 1986), the present results represent the first report of a dose-response for the growth-potentiating (enhancing) activity of AFP. The dual activities of AFP 
preparations regarding uterine growth regulation display comparable yet contrasting dose responsiveness. Both assay graphs (Fig. 1) showed peak activities of $1.0 \mu \mathrm{g} / \mathrm{mouse}$. Yet each graphic titration reflected the mirror image of the other regarding the rise and fall of uterine responsiveness throughout the AFP dose range tested.

Both bioassays (immature and ovariectomized adult mice) can be utilized to demonstrate the uterine growth-regulatory properties of AFP preparations. We deemed it important to show that AFP, a fetal protein, displayed growth regulatory activity in vivo both in adult and immature tissues, suggesting a similarity of cellular mechanisms. The adult mouse uterus must therefore retain the same ability to respond to a fetal/neonatal oestrogen-response protein as does the immature uterus.

Finally, the 2 animal assays for the biological activities of AFP preparations should be compared on the basis of utility. The immature mouse bioassay, although dependent on seasonality, provides a simple procedure in an easily obtainable animal source. With the development of the 3day assay, the procedure was rendered usable in any season. In contrast, the ovariectomized adult mouse model, although more sensitive for AFP preparations, required that surgery be performed on each animal before testing and that larger doses of purified AFP preparations $(5 \mu \mathrm{g} / \mathrm{mouse})$ be used to demonstrate nearly complete inhibition $(82 \%)$ of uterine oestrogen responsiveness. The immature mice are more economical to house, easier to produce (by matings) and maintain, and require no surgical preparations or post-surgical lag time before testing. The 3-day bioassay procedure can be easily used to test the biological activities of various AFP preparations and properties of AFP such as in-vivo immunoregulatory activities or in-vitro oestrogen binding assays.

\section{References}

Abelev, G.I. (1971) Alpha-fetoprotein in association with malignant tumors. Advances in Cancer Res. 14, 295-357.

Abelev, G.I., Perova, S.D., Khramkova, N.I., Postinikova, E.A. \& Irlin, I.S. (1963) Production of embryonal alpha-globulin by transplantable mouse hepatoma. Transpl. Bull. 1, 174-177.

Allen, R.P. \& Mizejewski, G.J. (1977) Isolation and characterization of alphafetoprotein from the murine hepatoma BW7756. Biochim. Biophys. Acta 491, 242-252.

Aoyagi, Y., Ikenada, T. \& Ichida, F. (1978) Copper (II)binding ability of human alpha-fetoprotein. Cancer Res. 38, 3483-3486.

Bergstrand, C.G. \& Czar, B. (1957) Paper electrophoretic study of human fetal serum proteins with demonstration of a new protein fraction. Scand. J. clin. Lab. Invest. 9, 277-280.

Boyd, P.A. \& Spelsberg, T.C. (1979) Seasonal changes in the molecular species and nuclear binding of the chick oviduct progesterone receptor. Biochemistry, N.Y. 17, 3685-3690.

Brock, D.J.H. \& Sutcliffe, R.G. (1972) Alpha-fetoprotein in the antenatal diagnosis of anencephaly and spina bifida. Lancet 2, 197-198.

Hilgar, A.G. \& Palmore, J., Jr (1965) The uterotrophic evaluation of steroids and other compounds. In Uterotrophic Bioassay Data Issue 13, pp. 1-10. Eds A. G. Hilgar \& L. Trench. U.S. Dept. HEW, NIH, Bethesda.

Jacobson, H.I. \& Mizejewski, G.J. (1985) Assay of estrogen-response modulating activity in alpha-fetoprotein. Fedn Proc. Fedn Am. Socs exp. Biol. 44, 423. Abstr.
Joshi, S.G. \& Ebert, K.M. (1976) Effects of progesterone on labelling of soluble proteins and glycoproteins in rabbit endometrium. Fert. Steril. 27, 730-739.

Kelleher, P.C., Smith, C.F. \& Pannell, R. (1979) Chromatography of nonhuman albumins on Cibacron Blue-agarose. Application to the separation of albumin from rat alpha-fetoprotein. J. Chromatogr. 173, 415-418.

Kithier, K., Houstek, J., Masopust, J. \& Radl, J. (1966) Occurrence of a specific fetal protein in a primary liver carcinoma. Nature, Lond. 212, 414-415.

Laurell, C.B. (1966) Quantitative estimation of proteins by electrophoresis in antibody-containing agarose gel. Antigen-antibody crossed electrophoresis. Analyt. Biochem. 15, 45-22.

Leek, A.E., Ruoss, C.F., Kitau, M.J. \& Chard, T. (1973) Raised AFP in maternal serum with anencephalic pregnancy. Lancet ii, 385-386.

Lowry, O.H., Rosebrough, N.J., Farr, A.L. \& Randall, R.J. (1951) Protein measurement with Folin phenol reagent. J. biol. Chem. 193, 265-275.

Mancini, G., Carbonara, A.O. \& Heremans, J.F. (1965) Immunochemical quantitation of antigens by single radial immunodiffusion. Immunochemistry 2, 235-254.

Mizejewski, G.J. \& Allen, R.P. (1978) Alpha-fetoprotein: studies of tumor associated antigen cytotoxicity in mouse hepatoma BW7756. Clin. Immunol. Immunopathol. 11, 307-317

Mizejewski, G.J. \& Jacobson, H.I. (1987) Alphafetoprotein is a dual regulator of growth in estrogen responsive tissues. In Biological Activities of Alphafetoprotein, pp. 72-82. Eds G. J. Mizejewski \& H. I. Jacobson. CRC Press, Boca Raton.

Mizejewski, G.J., Simon, R. \& Vonnegut, M. (1979a) 
Purification of alpha-fetoprotein from mouse amniotic fluid by gel-entrapped antibody filtration, $J$. Immunol. Methods 31, 333-339.

Mizejewski, G.J., Plummer, J., Blanchett, K., Vonnegut, M. \& Jacobson, H. (1979b) Alpha-fetoprotein: immunoreactivity of the major estradiol-binding component in mouse amniotic fluid. Immunology 36, 685, Abstr.

Mizejewski, G.J., Vonnegut, M. \& Simon, R. (1980) Estradiol affinity chromatography: application to purification of murine alpha-fetoprotein. $J$. Chromatogr. 22, 113-121.

Mizejewski, G.J., Plummer, J.M. \& Jacobson, H.I. (1982) Stability of complex formation between estradiol and murine alpha-fetoprotein. Fedn Proc. Fedn Am. Socs. exp. Biol. 41, 7150. Abstr.

Mizejewski, G.J., Vonnegut, M. \& Jacobson, H.I. (1983) Estradiol-activated alpha-fetoprotein suppresses the uterotrophic response to estrogens. Proc. natn Acad. Sci. U.S.A. 80, 2733-2737.

Mizejewski, G.J., Vonnegut, M. \& Jacobson, H.I. (1986) Studies of the intrinsic antiuterotropic activity of murine alpha-fetoprotein. Tumor Biol. 7, 19-36.

Nunez, E.A. (1986) Facteurs influencant le dosage de l'alpha-fetoproteine. In Binding Proteins of Steroid Hormones (Colloque INSERM), vol. 149, pp. 237-244. John Libbey Eurotext Ltd, Paris.
Ouchterlony, O. (1968) Handbook of Immunodiffusion and Immunoelectrophoresis, pp. 21-25. Ann Arbor Science Publishers, Ann Arbor.

Raynaud, J.P. (1973) Influence of rat estradiol binding plasma protein (EBP) on uterotrophic activity. Steroids 21, 249-258.

Savu, L., Benassayag, C., Vallette, G., Christeff, N. \& Nunez, E. (1981) Mouse alpha-fetoprotein and albumin. A comparison of their binding properties with estrogen and fatty acid ligands. J. biol. Chem. 256, 9414-9418.

Scheidigger, J.J. (1955) Une micromethode de l'immunoelectrophorese. Int. Arch. Allergy appl. Immunol. 7, 103-109.

Soubiran, P., Mucchielli, A., Kerckaert, J.P., Bayard, B. \& Masseyeff, R. (1979) Stimulatory effect of human alpha-fetoprotein and its molecular variants on in vitro induced lymphocyte blastogenesis. Scand. $J$. Immunol. 10, 179-186.

Tatarinov, Y.S. (1964) Fetal alpha-globulin in the sera of patients with primary liver tumors. Proc. Ist Int. Biochem. Congress, Moscow 2, 274, Abstr.

Toder, V., Bland, M., Gold-Gefter, L. \& Nebel, L. (1983) The effect of alpha-fetoprotein on the growth of placental cells in vitro. Placenta 4, 79-86.

Received 16 May 1988 